\title{
ANALISIS STRATEGI KOMUNIKASI DALAM PEMASARAN WISATA KAMPUNG BUDAYA SINDANGBARANG
}

\section{Analysis of Communication Strategies in Marketing of Kampung Budaya Sindangbarang Tourism}

\author{
Shofa Maghfirah ${ }^{*}$, Sumardjo \\ ${ }^{1}$ Departemen Sains Komunikasi dan Pengembangan Masyarakat, Fakultas Ekologi Manusia, Institut Pertanian Bogor, \\ Dramaga Bogor, 16680, Indonesia \\ ${ }^{*}$ E-mail korespondensi: shofamaghfirah@gmail.com
}

Diterima: 23-10-21 | Disetujui: 19-01-22 | Publikasi online: 20-01-22

\begin{abstract}
Tourism is one form of development that can produce economic growth accompanied by regional growth in a place, in a city or in a village. The development of village tourism has been facilitated by the state, but it turns out that the community tends to be passive. As a result, local capacity in responding to state-sponsored innovations through the development of tourist villages still faces a number of crucial problems. This research was conducted to find out how the right marketing communication strategy is used for Sindangbarang Cultural Village tourism. This study selected the research location of the Sindangbarang Cultural Village, which is considered potential as a cultural tourism location in Bogor. This research was conducted using the census method with respondents who are managers of the Sindangbarang Cultural Village tourism and supported by qualitative data, namely the in-depth interview method which was proposed to several stakeholders related to this research. This research is taken from the point of view or perception of permanent managers as respondents. The results of this study indicate that consumers from the Sindangbarang Cultural Village are people in the age range of children and adolescents. The relationship between the marketing mix carried out by the manager of the Sindangbarang Cultural Village and the tourism benefits obtained by the village is strong, indicated by the increase in income and the opening of business opportunities for the village community.
\end{abstract}

Kata kunci: communication, Kampung Budaya Sindangbarang, Marketing Strategy

\section{ABSTRAK}

Pariwisata merupakan salah satu bentuk dari pengembangan yang dapat menghasilkan pertumbuhan ekonomi disertai pertumbuhan Kawasan di suatu tempat, di kota maupun di desa. Pengembangan pariwisata desa telah banyak difasilitasi oleh negara, namun ternyata masyarakat cenderung pasif. Akibatkan kapasitas lokal di dalam merespon inovasi yang disponsori oleh negara melalui pembangunan desa wisata masih menghadapi sejumlah persoalan krusial. Penelitian ini dilakukan untuk mengetahui bagaimana strategi komunikasi pemasaran yang tepat digunakan untuk wisata Kampung Budaya Sindangbarang. Kajian ini dipilih lokasi penelitian Kampung Budaya Sindangbarang, yang dinilai potensial sebagai lokasi wisata budaya di Bogor. Penelitian ini dilakukan dengan metode sensus dengan responden yang merupakan pengelola dari wisata Kampung Budaya Sindangbarang dan didukung oleh data kualitatif yaitu dengan metode wawancara mendalam yang diajukan kepada beberapa pemangku kepentingan terkait dengan penelitian ini. Penelitian ini diambil dari sudut pandang atau persepsi pengelola tetap sebagai responden. Hasil dari penelitian ini menunjukkan bahwa konsumen dari Kampung Budaya Sindangbarang merupakan masyarakat dalam rentang usia anak-anak dan remaja. Hubungan bauran pemasaran yang dilakukan oleh pengelola Kampung Budaya Sindangbarang dengan manfaat wisata yang didapatkan oleh desa bersifat kuat, diindikasikan dari meningkatnya pendapatan dan terbukanya peluang usaha bagi masyarakat desa

Kata kunci: Komunikasi, Kampung Budaya Sindangbarang, Strategi Pemasaran

Content from this work may be used under the terms of the Creative Commons Attribution-ShareAlike 4.0 International. Any further distribution of this work must maintain attribution to the author(s) and the title of the work, journal citation and DOI. 


\section{PENDAHULUAN}

Pariwisata merupakan salah satu bentuk dari pengembangan yang akan dapat menghasilkan pertumbuhan ekonomi disertai pertumbuhan kawaan di suatu tempat, di kota maupun di desa (Wulan dan Khadiyanto, 2013). Namun, pada Faktanya pengembangan pariwisata desa di Indonesia lebih banyak difasilitasi oleh negara, sehingga masyarakat cenderung pasif (Damanik, 2009). Hal ini mengakibatkan kapasitas lokal di dalam merespon inovasi yang disponsori oleh negara melalui pembangunan desa wisata masih menghadapi sejumlah persoalan krusial. Menurut Undang-Undang No. 10 Tahun 2009 tentang Kepariwisataan, menyebutkan bahwa pembangunan kepariwisataan diperlukan untuk mendorong pemerataan kesempatan berusaha dan memperoleh manfaat serta mampu menghadapi tantangan perubahan kehidupan lokal, nasional, dan global.

Mengacu pada Shimp (2008) \& Widyastuti (2017), Integrated Marketing Communication (IMC) adalah sebuah proses pengembangan dan implementasi bentuk program persuasif kepada pelanggan dan calon pelanggan secara berkelanjutan. Tujuan dari IMC adalah mempengaruhi atau memberikan efek langsung kepada perilaku khalayak sasaran yang dimilikinya. Strategi pemasaran tentunya menjadi elemen penting sebagai acuan inovasi pemasaran guna mengembangkan pariwisata desa. Menurut Kotler (2009), hal yang penting dalam pemasaran produk antara lain: Segmenting, targeting, dan positioning.

Desa Wisata adalah pariwisata yang terdiri dari keseluruhan pengalaman pedesaan, atraksi alam, tradisi, unsur-unsur yang unik, yang secara keseluruhan dapat menarik minat wisatawan (Joshi, 2012). Melalui desa wisata, pariwisata membuktikan keberpihakannya kepada semangat pariwisata sebagai penyerap tenaga kerja pedesaaan, sebagai penggerak pertumbuhan ekonomi wilayah, dan sebagai alat pengentasan kemiskinan (Antara, 2015). Lahirnya Undang-Undang No. 6 Tahun 2014 tentang Desa, telah menerbitkan harapan bagi desa. Undang - Undang tersebut mengamanatkan untuk setiap desa di Indonesia harus memiliki Badan Usaha Milik Desa yang memiliki mandat menjalankan usaha-usaha yang bersifat produktif, sehingga mampu memakmurkan desa.

Desa Pasir Eurih merupakan sebuah desa yang terletak di Kecamatan Tamansari, Kabupaten Bogor. Salah satu objek wisata yang terdapat di desa tersebut adalah Kampung Budaya Sindangbarang. Wisata ini mengenalkan budaya sunda melalui objek dan tradisi adat istiadat seperti adanya bangunan rumah adat sunda, mengenalkan tarian-tarian, upacara adat, dan kegiatan budaya lainnya. Kampung Budaya Sindangbarang dibangun pada tahun 2006 oleh pemerintah kabupaten Bogor bekerjasama dengan masyarakat setempat. Saat ini, Kampung Budaya Sindangbarang banyak dikunjungi oleh wisatawan lokal maupun mancanegara dengan tujuan edukasi budaya Jawa Barat.

Melalui penjelasan yang telah dipaparkan, maka muncul pertanyaan penelitian berupa Bagaimana strategi pemasaran yang tepat yang dibutuhkan untuk pengembangan desa wisata menurut persepsi pengelola Kampung Budaya Sindangbarang? Dan Bagaimana hubungan antara strategi komunikasi pemasaran dengan tingkat bauran promosi yang dilakukan oleh pengelola Kampung Budaya Sindangbarang?

Maka tujuan dari pelaksanaan penelitian ini adalah untuk menganalisis strategi komunikasi dalam pemasaran desa wisata Kampung Budaya Sindangbarang dan menganalisis peran strategi komunikasi pemasaran terhadap manfaat desa wisata Kampung Budaya Sindangbarang menurut persepsi pengelola wisata

\section{METODE PENELITIAN}

\section{Pendekatan dan Metode Penelitian}

Penelitian ini menggunakan dua pendekatan yaitu pendekatan kuantitatif dan didukung oleh pendekatan kualitatif. Pendekatan kuantitatif dilakukan dengan metode kuisioner. Sedangkan, pendekatan kuantitatif dilakukan dengan metode wawancara. Penelitian ini termasuk ke dalam penelitian eksplanatori atau penjelasan. Kuesioner dibagikan kepada pengelola Kampung Budaya Sindangbarang, karena penelitian ini diambil dari persepsi pengelola karena penelitian ini dilakukan saat pandemic dan melihat berkurangnya pengunjung yang datang. 


\section{Lokasi dan Waktu Penelitian}

Penelitian ini akan dilakukan di lokasi wisata Kampung Budaya Sindangbarang, Desa Pasir Eurih, Kecamatan Tamansari, Kabupaten Bogor. Penentuan lokasi ini dilakukan secara sengaja (purposive) berdasarkan hasil studi literatur dari beberapa sumber ilmiah dan terpercaya. Penelitian ini akan dilaksanakan dalam jangka waktu kurang lebih enam bulan, sejak bulan Januari 2020 hingga September 2021.

\section{Teknik Pengumpulan Data}

Penelitian ini menggunakan dua jenis data, yaitu data primer dan data sekunder. Data primer diperoleh secara langsung dari obyek yang akan diteliti seperti hasil observasi, kuesioner, dan wawancara. Data sekunder dapat diperoleh dari studi literatur seperti buku, jurnal, prosiding, ataupun karya ilmiah terdahulu.

\section{Teknik Penentuan Responden dan Informan}

Responden dalam penelitian ini adalah pengelola desa wisata Kampung Budaya Sindangbarang yang juga merupakan masyarakat Desa Pasir Eurih. Jumlah pengelola dari desa wisata secara keseluruhan mencapai 100 berdasarkan data pengelola desa wisata Kampung Budaya Sindangbarang, 30 di antaranya dipersiapkan sebagai pengelola tetap. Ke 30 personel pengelola tetap ini telah dipilih sebagai responden dari penelitian ini. Pengambilan responden dilakukan dengan metode sensus. Sedangkan, informan dari penelitian ini adalah aparat desa, ketua RT setempat, serta stakeholder terkait wisata Kampung Budaya Sindangbarang. Pengukuran variabel penelitian menggunakan proksi pengelola, dan bukan konsumen, hal ini diakukan mengingat saat pandemic Covid 19, sulit untuk mendapatkan responden karena ketentuan Prokes tidak memungkinkan untuk itu.

\section{Teknik Pengolahan dan Analisis Data}

Penelitian ini memiliki dua jenis data yang diolah dan dianalisis yaitu data kuantitatif dan data kualitatif. Data yang diperoleh secara kuantitatif melalui kuesioner diolah dengan menggunakan program Microsoft Excel 2013 dan SPSS 24.0 ke dalam bentuk Tabel.

Sedangkan, SPSS 24.0 for windows digunakan untuk membuat uji statistik dalam menganalisis hubungan antara strategi komunikasi pemasaran dengan tingkat wisatawan Kampung Budaya SIndangbarang yang berskala ordinal dan nominal.

Data kualitatif akan menjadi data pendukung kebenaran data kuantitatif yang dianalisis melalui tiga tahap yakni reduksi data, penyajian data, dan verifikasi. Analisis data kualitatif disajikan dalam bentuk narasi. Analisis hubungan dalam penelitian ini akan di uji menggunakan metode rank spearman.

Uji korelasi spearman dipilih dalam penelitian ini karena jenis data yang akan diolah merupakan data ordinal. Korelasi spearman dilambangkan dengan $\left(\mathrm{r}_{\mathrm{s}}\right)$ dengan ketentuan nilai $\mathrm{r}_{\mathrm{s}}$ tidak lebih dari harga ($\left.1<r_{s}<+1\right)$. Apabila $r_{s}=-1$, artinya korelasi negatif sempurna. Adapun $r s=0$ artinya tidak ada korelasi. Rs $=1$ artiya nilai korelasinya sangat kuat. (Riduwan, 2008).

$$
r_{s}=1-\frac{6 \Sigma d_{i}^{2}}{n\left(n^{2}-1\right)}
$$




\section{HASIL DAN PEMBAHASAN}

Tabel 1. Jumlah dan Persentase Responden Berdasarkan Strategi Komunikasi Pemasaran pada Kampung Budaya Sindangbarang Tahun 2021

\begin{tabular}{|c|c|c|}
\hline \multirow{2}{*}{ Strategi Komunikasi Pemasaran } & \multicolumn{2}{|c|}{ Jumlah } \\
\hline & $\mathrm{n}$ & $\%$ \\
\hline \multicolumn{3}{|l|}{ Segmentasi Jenis kelamin } \\
\hline Laki-laki & 26 & 86.7 \\
\hline Perempuan & 4 & 13.3 \\
\hline Total & 30 & 100.0 \\
\hline \multicolumn{3}{|l|}{ Segmentasi Kelompok Usia } \\
\hline Anak-anak & 11 & 36.7 \\
\hline Remaja & 14 & 46.6 \\
\hline Dewasa & 5 & 16.7 \\
\hline Total & 30 & 100.0 \\
\hline \multicolumn{3}{|l|}{ Segmentasi Kepentingan Berwisata } \\
\hline Akademik & 25 & 83.3 \\
\hline Berwisata & 5 & 16.7 \\
\hline Total & 30 & 100.0 \\
\hline \multicolumn{3}{|l|}{ Segmentasi Domisili tempat tinggal } \\
\hline Bogor & 5 & 16.7 \\
\hline Jadetabek & 25 & 83.3 \\
\hline Total & 30 & 100.0 \\
\hline \multicolumn{3}{|l|}{ Target } \\
\hline Segmen sudah dibidik dan ditetapkan & 18 & 60.0 \\
\hline Seluruh segmen & 12 & 40.0 \\
\hline Total & 30 & 100.0 \\
\hline \multicolumn{3}{|l|}{ Posisi } \\
\hline Rendah & 3 & 10.0 \\
\hline Sedang & 14 & 46.7 \\
\hline Tinggi & 13 & 43.3 \\
\hline Total & 30 & 100.0 \\
\hline
\end{tabular}

\section{Segmentasi}

Sejumlah $86.6 \%$ pengelola menjawab bahwa ayoritas jenis kelamin pengunjung yang datang ke Kampung Budaya adalah laki-laki. Hal ini dikarenakan Kampung Budaya Sindangbarang merupakan wisata yang berbasis budaya dengan menawarkan ilmu pengetahuan mengenai budaya sunda, laki-laki lebih memiliki keingintahuan yang tinggi dibanding perempuan sehingga responden berpendapat bahwa pengunjung Kampung Budaya Sindangbarang mayoritas adalah laki-laki. Selain itu, laki-laki dianggap lebih fleksibel dalam melakukan perjalanan wisata dibandingkan dengan perempuan.

Segmentasi kelompok usia menunjukkan bahwa sejumlah $46.6 \%$ pengelola menjawab bahwa pengunjung Kampung Budaya Sindangbarang Sebagian besar adalah remaja dikarenakan rentang usia remaja banyak yang sedang mencari data untuk kebutuhan penelitian. Selain itu, remaja merupakan usia dimana seseorang sedang banyak mencari tahu mengenai hal baru dan ingin merasakan pengalaman baru.

Sejumlah $83.3 \%$ pengelola menjawab bahwa Sebagian besar pengunjung yang datang ke Kampung Budaya Sindangbarang memiliki kepentingan penelitian atau akademik dikarenakan Kampung Budaya Sindangbarang merupakan wisata yang menawarkan suguhan budaya sunda sehingga sebagian besar orang yang berkunjung selain ingin berwisata adalah ingin melakukan penelitian yang berstatus sebagai siswa, pelajar atau mahasiswa.

\section{Target}

Dalam penelitian ini target merupakan proses memilih segmen pasar yang paling sesuai atau potensial pada Kampung Budaya Sindangbarang. Berdasarkan hasil analisis pada Tabel 1 adalah sejumlah $60 \%$ pengelola atau responden berpendapat bahwa Kampung Budaya Sindangbarang sudah menentukan 
siapa saja yang menjadi target. Target yang dituju adalah golongan masyarakat yang ingin mempelajari budaya dan sejarah Jawa Barat.

\section{Posisi}

Posisi Kampung Budaya Sindangbarang sudah termasuk aman dikarenakan hanya sedikit objek wisata yang memiliki konsep yang sama dengan Kampung Budaya Sindangbarang di Wilayah Bogor yaitu Kampoeng Wisata Cinangneng. Hal ini dikemukakan oleh $46.7 \%$ pengelola. Selain itu, responden menyatakan bahwa Sebagian besar pengunjung merasa puas dengan pelayanan ataupun atraksi yang ditawarkan di Kampung Budaya Sindangbarang sehingga tidak komentar negatif yang berarti dari pengunjung yang pernah berwisata ke Kampung Budaya Sindangbarang.

Tabel 2. Jumlah dan Persentase Responden Berdasarkan Tingkat Bauran Pemasaran pada Kampung Budaya Sindangbarang Tahun 2021

\begin{tabular}{|c|c|c|}
\hline \multirow{2}{*}{ Bauran Pemasaran } & \multicolumn{2}{|c|}{ Jumlah } \\
\hline & $\mathrm{n}$ & $\%$ \\
\hline \multicolumn{3}{|l|}{ Periklanan } \\
\hline Rendah & 2 & 6.6 \\
\hline Sedang & 14 & 46.7 \\
\hline Tinggi & 14 & 46.7 \\
\hline Total & 30 & 100.0 \\
\hline \multicolumn{3}{|l|}{ Penjualan Personal } \\
\hline Rendah & 5 & 16.7 \\
\hline Sedang & 25 & 83.3 \\
\hline Total & 30 & 100.0 \\
\hline \multicolumn{3}{|l|}{ Promosi Penjualan } \\
\hline Rendah & 2 & 6.7 \\
\hline Sedang & 13 & 43.3 \\
\hline Tinggi & 15 & 50.0 \\
\hline Total & 30 & 100.0 \\
\hline \multicolumn{3}{|l|}{ Hubungan Masyarakat } \\
\hline Rendah & 4 & 13.3 \\
\hline Sedang & 13 & 43.3 \\
\hline Tinggi & 13 & 43.3 \\
\hline Total & 30 & 100.0 \\
\hline \multicolumn{3}{|l|}{ Pemasaran Langsung } \\
\hline Rendah & 3 & 10.0 \\
\hline Sedang & 23 & 76.7 \\
\hline Tinggi & 4 & 13.3 \\
\hline Total & 30 & 100.0 \\
\hline \multicolumn{3}{|l|}{ Total Bauran Pemasaran } \\
\hline Rendah & 2 & 6.7 \\
\hline Sedang & 20 & 66.7 \\
\hline Tinggi & 8 & 26.6 \\
\hline Total & 30 & 100.0 \\
\hline
\end{tabular}

\section{Periklanan}

Sebanyak $46.6 \%$ pengelola menjawab bahwa sudah melakukan berbagai aktivitas periklanan. Iklan yang dilakukan pihak pengelola Kampung Budaya Sindangbarang dalam bentuk brosur yang nantinya akan dibagikan ke masyarakat luas, selain itu, pihak pengelola Kampung Budaya Sindangbarang juga menggunakan media sosial seperti website, instagram, dan juga facebook untuk memasarkan Kampung Budaya Sindangbarang ke khalayak.

\section{Penjualan Personal}

Bentuk dari penjualan personal yang diaplikasikan oleh pengelola Kampung Budaya Sindangbarang hanya melakukan penjualan personal dengan cara mendatangi anak-anak Sekolah Dasar (SD) sekaligus untuk mengedukasi mereka mengenai budaya Jawa Barat. Pihak pengelola Kampung Budaya 
Sindangbarang belum memaksimalkan dalam melakukan penjualan personal dikarenakan saat ini masih dalam keadaan pandemic.

\section{Promosi Penjualan}

Promosi penjualan sudah dilakukan secara maksimal oleh pengelola Kampung Budaya Sindangbarang berupa tambahan atraksi atau layanan apabila pengunjung mengambil paket yang sudah disediakan untuk rombongan yang berjumlah banyak. Selain itu, pengelola Kampung Budaya Sindangbarang juga memberikan potongan harga apabila wisatawan berkunjung dalam jumlah banyak.

\section{Hubungan Masyarakat}

Hubungan masyarakat yang dilakukan pengelola Kampung Budaya Sindangbarang dapat berupa hubungan baik dengan masyarakat sekitar, pemecahan masalah bersama masyarakat sekitar, dan kegiatan yang melibatkan partisipasi masyarakat sekitar. Peran serta masyarakat sekitar Kampung Budaya Sindangbarang sangat memiliki pengaruh dengan keberlangsungan kegiatan wisata di Kampung Budaya Sindangbarang dikarenakan Kampung Budaya Sindangbarang terletak di sekitar pemukiman warga lokal.

\section{Pemasaran Langsung}

Pihak pengelola Kampung Budaya Sindangbarang tidak selalu melakukan pemasaran langung dengan cara mengirimkan pesan teks melalui media sosial, hanya sesekali saja. Tetapi, pengelola Kampung Budaya Sindangbarang sering melakukan pemasaran langsung secara interaktif dengan cara menawarkan kepada kerabat mereka ataupun orang yang mereka temui.

\section{Hubungan antara Strategi Komunikasi Pemasaran dengan Bauran Pemasaran Berdasarkan Korelasi Rank Spearman dan Pearson Chi-Square}

Tabel 3. Koefisien Korelasi Rank Spearman $\left(\mathrm{r}_{\mathrm{s}}\right)$ dan Pearson Chi Square Hubungan Strategi Komunikasi Pemasaran dengan Bauran Pemasaran

\begin{tabular}{|c|c|c|c|c|c|}
\hline \multirow{2}{*}{$\begin{array}{c}\text { Strategi } \\
\text { Komunikasi } \\
\text { Pemasaran }\end{array}$} & \multicolumn{5}{|c|}{ Bauran Pemasaran } \\
\hline & Periklanan & $\begin{array}{c}\text { Penjualan } \\
\text { Personal }\end{array}$ & $\begin{array}{l}\text { Promosi } \\
\text { Penjualan }\end{array}$ & $\begin{array}{l}\text { Hubungan } \\
\text { Masyarakat }\end{array}$ & $\begin{array}{c}\text { Pemasaran } \\
\text { Langsung }\end{array}$ \\
\hline Target $\left(\mathrm{X}^{2}\right)$ & $\begin{array}{l}0.490 \\
(\mathrm{df}=2)\end{array}$ & $\begin{array}{c}\mathbf{0 . 0 3 2} \\
(\mathrm{df}=1)\end{array}$ & $\begin{array}{c}\mathbf{0 . 0 4 1} \\
(\mathrm{df}=2)\end{array}$ & $\begin{array}{c}0.743 \\
(\mathrm{df}=2)\end{array}$ & $\begin{array}{l}\mathbf{0 . 0 3 9} \\
(\mathrm{df}=2)\end{array}$ \\
\hline Posisi $\left(\mathrm{R}_{\mathrm{s}}\right)$ & $0.830 * *$ & 0.229 & $0.422 *$ & 0.201 & 0.116 \\
\hline
\end{tabular}

Keterangan: $\quad \mathrm{n}=30 ; *$ = hubugan nyata $(\alpha<0.05) ; * *=$ hubungan sangat nyata $(\alpha<0.01)$

Target memiliki hubungan yang nyata dengan bauran pemasaran dari aspek penjualan personal, promosi penjualan dan pemasaran langsung karena nilai signifikansi lebih kecil dari 0.05 dan nilai Chi-square hitung lebih lebih besar dari nilai Chi-square Tabel pada $\mathrm{df}=1 \mathrm{dan} \mathrm{df}=2$. Hal tersebut dikarenakan target dari Kampung Budaya Sindangbarang sudah ditentukan yaitu akademisi sehingga tidak memiliki pengaruh dengan periklanan

Target memiliki pengaruh dengan penjualan personal dikarenakan jika target sudah ditentukan dan memiliki jumlah yang banyak atau luas, penjualan personal dapat dilakukan dengan ditujukan untuk melakukan pendekatan penjualan personal sesuai dengan target yang sudah dibidik. Target memiliki hubungan dengan promosi penjualan karena jika target sudah ditentukan, maka pengelola Kampung Budaya Sindangbarang dapat dengan mudah menentukan promosi penjualan apa saja yang akan disediakan untuk menarik perhatian target pengunjung tersebut. Target tidak berhubungan dengan hubungan masyarakat dikarenakan hubungan masyarakat yang dimaksud dalam pemenlitian ini adalah hubungan baik pengelola Kampung Budaya Sindangbarang dengan masyarakat sekitar Kampung Budaya Sindangbarang sehingga tidak berhubungan dengan wisatawan atau pengunjung. Target memiliki hubungan dengan pemasaran langsung dikarenakan jika target sudah ditentukan maka akan mudah dalam melakukan pemasaran langsung untuk membidik target yang dimaksud

Posisi memiliki hubungan yang sangat nyata dengan periklanan dengan nilai signifikansi dibawah 0,01 dan koefisien korelasi sebesar 0,830 yang menunjukkan bahwa kekuatan hubungan antara posisi dengan periklanan adalah sangat kuat. Hal ini dikarenakan periklanan cukup mampu mempengaruhi sisi psikologis dari calon pengunjung terutama untuk membantu pengunjung dalam mengingat Kampung Budaya Sindangbarang di benaknya. Periklanan cukup mampu merangsang calon konsumen agar 
tertarik untuk melakukan pembelian atau kunjungan ke Kampung Budaya Sindangbarang sehingga posisi Kampung Budaya Sindangbarang dapat lebih unggul dibandingkan dengan posisi pesaing. Posisi memiliki hubungan yang nyata dengan promosi penjualan dengan nilai signifikansi dibawah 0,05 dan koefisien korelasi sebesar 0,422 yang menunjukkan bahwa hubungan posisi dengan promosi penjualan adalah cukup. Hal tersebut dikarenakan promosi penjualan menjadi salah satu hal yang dapat menarik calon pengunjung untuk datang ke Kampung Budaya Sindangbarang dengan jumah banyak ataupun dengan frekuensi yang sering. Hal tersebut dapat meningkatkan posisi Kampung Budaya Sindangbarang di benak pengunjung.

Tabel 4. Jumlah dan Persentase Responden Berdasarkan Tingkat Manfaat Desa Wisata pada Kampung Budaya Sindangbarang Tahun 2021

\begin{tabular}{|c|c|c|}
\hline \multirow{2}{*}{ Manfaat Desa Wisata } & \multicolumn{2}{|c|}{ Jumlah } \\
\hline & $\mathrm{n}$ & $\%$ \\
\hline \multicolumn{3}{|l|}{ Atraksi } \\
\hline Sedang & 16 & 53.3 \\
\hline Tinggi & 14 & 46.7 \\
\hline Total & 30 & 100.0 \\
\hline \multicolumn{3}{|l|}{ Akomodasi } \\
\hline Sedang & 18 & 60.0 \\
\hline Tinggi & 12 & 40.0 \\
\hline Total & 30 & 100.0 \\
\hline \multicolumn{3}{|l|}{ Peluang Usaha } \\
\hline Rendah & 2 & 6.7 \\
\hline Sedang & 13 & 43.3 \\
\hline Tinggi & 15 & 50.0 \\
\hline Total & 30 & 100.0 \\
\hline \multicolumn{3}{|l|}{ Peningkatan Partisipasi Masyarakat } \\
\hline Rendah & 6 & 20.0 \\
\hline Sedang & 13 & 43.3 \\
\hline Tinggi & 11 & 36.7 \\
\hline Total & 30 & 100.0 \\
\hline \multicolumn{3}{|l|}{ Total Manfaat Desa Wisata } \\
\hline Rendah & 4 & 13.3 \\
\hline Sedang & 15 & 50.0 \\
\hline Tinggi & 11 & 36.7 \\
\hline Total & 30 & 100.0 \\
\hline
\end{tabular}

\title{
Atraksi
}

Menurut penuturan pengelola melalui pengisian kuesioner, atraksi di Kampung Budaya Sindangbarang sudah cukup menarik bagi pengunjung serta membawa manfaat baik untuk pengunjung dan juga pengelola Kampung Budaya Sindangbarang. Manfaat yang dirasakan oleh pengunjung dan pengelola Kampung Budaya Sindangbarang adalah meningkatnya pengetahuan dan juga rasa cinta terhadap kebudayaan sunda yang memang semuanya disuguhkan pada atraksi yang ditampilkan. Anak-anak yang berkunjung jadi lebih memahami apa saja budaya sunda yang patut dilestarikan agar tidak punah tergores oleh jaman. Selain itu, atraksi yang ditampilkan juga dapat meningkatkan keterampilan pengelola dan pengunjung, dikarenakan mereka dapat sama-sama mempelajari bagaimana carannya melakukan atraksi-atraksi tersebut.

\begin{abstract}
Akomodasi
Akomodasi yang disediakan oleh masyarakat dan penglola Kampung Budaya Sindangbarang sudah cukup membantu pengunjung yang kesulitan akses untuk masuk ke Kampung Budaya Sindangbarang dikarenakan jalanan yang kecil dan tidak bisa dilalui oleh bis, akomodasi tersebut berupa angkot yang dimiliki oleh masyarakat sekitar Kampung Budaya Sindangbarang. Biasanya pengunjung yang menggunakan angkot tersebut adalah pengunjung yang datang secara rombongan dengan menaiki bis, tetapi jika pengunjung yang datang menggunakan mobil pribadi atau motor biasanya tidak ada kendala mengenai akses jalan menuju Kampung Budaya Sindangbarang.
\end{abstract}




\section{Peluang Usaha}

Peluang usaha yang terdapat di Kampung Budaya Sindangbarang cukup memiliki manfaat dan dapat membantu kehidupan masyarakat sekitar Kampung Budaya Sindangbarang. Peluang usaha yang dimanfaatkan masyarakat sekitar paling banyak adalah pengelola dan juga penjual makan asongan di sekitar Kampung Budaya Sindangbarang.

\section{Peningkatan Partisipasi Masyarakat}

Semenjak adanya Kampung Budaya Sindangbarang, masyarakat sekitar biasa mengadakan acara tahunan di Kampung Budaya Sindangbarang agar acara lebih meriah dan dapat disaksikan langsung oleh pengunjung. Selain itu, dengan adanya desa wisata Kampung Budaya Sindangbarang ini, masyarakat dapat memiliki pemasukan atau mata pencaharian tambahan selain mata pencaharian utama apabila masyarakat aktif berpartisipasi dalam mendukung kegiatan pariwisata di Kampung Budaya Sindangbarang dan juga ikut menjaga kelestarian Kampung Budaya Sindangbarang.

\section{Hubungan antara Bauran Pemasaran dengan Manfaat Desa Wisata Berdasarkan Korelasi Rank Spearman}

Tabel 5. Koefisien Korelasi Rank Spearman $\left(\mathrm{r}_{\mathrm{s}}\right)$ Hubungan Bauran Pemasaran dengan Manfaat Desa Wisata

\begin{tabular}{llllll}
\hline \multicolumn{1}{c}{ Bauran Pemasaran } & \multicolumn{4}{c}{ Manfaat Desa Wisata } & $\begin{array}{c}\text { Seluruh } \\
\text { Aspek }\end{array}$ \\
\cline { 2 - 5 } & Atraksi & Akomodasi & $\begin{array}{c}\text { Peluang } \\
\text { Usaha }\end{array}$ & $\begin{array}{c}\text { Peningkatan } \\
\text { Partisipasi } \\
\text { Masyarakat }\end{array}$ & \\
\hline Periklanan & 0.000 & 0.018 & $0.683^{* *}$ & $0.397^{*}$ & 0.140 \\
Penjualan Personal & 0.120 & 0.183 & 0.301 & 0.022 & 0.213 \\
Promosi Penjualan & 0.061 & 0.053 & $0.780^{* *}$ & 0.198 & 0.142 \\
Hubungan masyarakat & 0.089 & 0.052 & $0.366^{*}$ & $0.681^{* *}$ & 0.199 \\
Pemasaran Langsung & 0.198 & 0.234 & 0.317 & 0.103 & 0.241 \\
\hline Bauran Pemasaran & 0.159 & 0.057 & $0.619^{* *}$ & $0.362^{*}$ & 0.213 \\
\hline
\end{tabular}

Keterangan: $\mathrm{n}=30 ; *=$ hubugan nyata $(\alpha<0.05) ; * *=$ hubungan sangat nyata $(\alpha<0.01)$

Terdapat hubungan yang sangat nyata antara periklanan dengan peluang usaha karena angka signifikansi dibawah 0.01 dengan nilai koefisien korelasi sebesar 0.683 menunjukkan bahwa kekuatan hubungan tersebut adalah kuat. Hal tersebut dikarenakan jika semakin tinggi iklan yang bertebaran mengenai Kampung Budaya Sindangbarang maka akan semakin tinggi pula peluang usaha yang dapat dilakukan oleh masyarakat sekitar Kampung Budaya Sindangbarang karena pengelola tempat wisata pastinya akan membutuhkan banyak karyawan dan tentunya karyawan tersebut akan diutamakan dari masyarakat sekitar terlebih dahulu sebelum ditawarkan dengan masyarakat di desa lain. Periklanan juga memilki hubungan yang nyata dengan peningkatan partisipasi masyarakat dengan angka signifikansi lebih kecil dari 0.05 dengan nilai koefisien korelasi sebesae 0.397 menunjukkan bahwa kekuatan hubungan tersebut adalah cukup. Hal tersebuut dikarenakan jika frekuensi iklan dan jumah iklan mengenai Kampung Budaya Sindangbarang semakin dapat diakses oleh khalayak, maka akan ada banyak kegiatan yang bisa dilakukan oleh masyarakat sekitar apabila jumlah pengunjung yang datang ke Kampung Budaya Sindangbarang semakin meningkat. Jika pengunjung semakin meningkat, pasti aka nada banyak kegiatan yang direncanakan oleh pengelola untuk ditampilkan dalam menyambut ataupun memberi kesan positif kepada wisatawan sehingga msyarakat akan lebih aktif dalam berpartisipasi dan menjaga keberlangsungan Kampung Budaya Sindangbarang.

Promosi penjualan memiliki hubungan dengan yang sangat nyata dengan peluang usaha dengan angka signifikansi lebih kecil dari 0.01 dan koefisien korelasi sebesar 0.780 menunjukkan bahwa kekuatan hubungan tersebut adalah sangat kuat karena apabila promosi dilakukan secara gencar dan wisatawan yang datang dalam jumlah banyak maka akan semakin banyak peluang usaha yang dapat dimanfaatkan oleh masyarakat sekitar Kampung Budaya Sindangbarang. Selain itu, hubungan masyarakat juga memiliki hubungan yang nyata dengan peluang usaha karena angka signifikansi dibawah 0.05 dan koefisien korelasi sebesar 0.366 menunjukkan kekuatan hubungan tersebut adalah cukup. Hal tersebut dikarenakan jika pengelola Kampung Budaya Sindangbarang memiliki keterkaitan yang erat dengan masyarakat sekitar, maka masyarakat sekitar akan lebih mudah dalam memanfaatkan peluang usaha yang tersedia dari adanya objek wisata Kampung Budaya Sindangbarang. Hubungan masyarakat 
memiliki hubungan yang sangat nyata dengan peningkatan partisipasi masyarakat karena angka signifikansi lebih kecil dari 0.01 dengan koefisien korelasi sebesar 0.681 menunjukkan bahwa kekuatan hubungan tersebut adalah kuat. Hal tersebut dikarenakan jika pengelola Kampung Budaya Sindangbarang memiliki keterkaitan atau hubungan yang baik dengan masyarakat sekitar, maka masyarakat akan aktif berpartisipasi dalam mendukung kegiatan wisata dan juga menjaga keberlangsungan objek wisata Kampung Budaya Sindangbarang sebab masyarakat akan lebih aktif apabila mereka kenal atau memiliki kedekatan personal dengan seseorang.

\section{KESIMPULAN}

Strategi komunikasi pemasaran yang digunakan oleh Kampung Budaya Sindangbarang adalah dengan menentukan segmentasi, target, dan juga posisi. Segmentasi yang ditentukan adalah kahalayak yang berprofesi sebagai dengan rentang usia dari anak-anak sampai dengan dewasa. Lalu segmentasi tempat tinggal masih di Wilayah Jabodetabek. Target dari wisatawan sudah dibidik da ditentukan dengan tujuaan untk mempermudah melakukan peneyebaran informasi maupun melakukan strategi promosi. Posisi Kampung Budaya Sindangbarang sejauh ini berada pada kategori sedang sebanyak 46,7 \% dikarenakan hanya sedikit objek wisata yang memiliki konsep yang sama dengan Kampung Budaya Sindangbarang di Wilayah Bogor yaitu Kampoeng Wisata Cinangneng. Selain itu, responden menyatakan bahwa Sebagian besar pengunjung merasa puas dengan pelayanan ataupun atraksi yang ditawarkan di Kampung Budaya Sindangbarang. Peran strategi komunikasi pemasaran yaitu dengan ditentukannya segmentasi, target, dan posisi maka dapat ditentukan pula bauran pemasaran yang nantinya akan dilakukan oleh pengelola Kampung Budaya Sindangbarang. Dengan ditentukannya target maka dapat ditingkatkan bauran pemasaran dalam aspek penjualan personal, promosi penjualan, dan pemasaran langsung. Meningkatkan periklanan juga dapat menentukan posisi suatu penyedia jasa karena iklan bertujuan untuk memberikan infomasi kepada khalayak mengenai produk atau jasa yang ditawarkan sehingga khalayak akan lebih mengingat mengenai Kampung Budaya Sindangbarang. Promosi penjualan juga dapat mempengaruhi posisi Kampung Budaya Sindangbarang dikarenakan masyarakat akan lebih merasa diuntungkan jika diberikan banyak promosi dan hal itu merupakan salah satu usaha untuk meningkatkan Kampung Budaya Sindangbarang dengan tempat wisata lainnya. Jika strategi-strategi bauran pemasaran tersebut ditingkatkan, tentunya akan dapat menarik banyak pengunjung yang berdampak pada meningkatnya peluang usaha serta meningkatnya partisipasi masyarakat.

\section{Saran}

Memanfaatkan secara maksimal media sosial dalam melakukan periklanan agar informasi mengenai Kampung Budaya Sindangbarang dapat lebih mudah diakses dan tersebar kepada masyarakat luas. Selain itu, disarankan juga untuk membuat paket-paket promosi yang lebih menarik dan bervariasi untuk menarik minat dan perhatian calon wisatawan untuk berkunjung ke Kampung Budaya Sindangbarang. Selain itu, perlu adanya perbaikan disejumlah titik dalam merespon keluhan pengunjung terutama di bidang akomodasi. Hal ini layak dijadikan pula sebagai pembelajaran untuk melihat efektivitas komunikasi pemasaran yang telah dilakukan dengan melihat fakta yang ada di lapang agar pemasaran yang sudah berjalan dapat sesuai dengan target atau tujuan yang telah ditentukan.

\section{DAFTAR PUSTAKA}

[UU] Undang Undang Republik Indonesia Nomor 10 Tahun 2009 tentang Kepariwisataan.

[UU] Undang-Undang Republik Indonesia Nomor 6 Tahun 2014 tentang Desa.

Antara M, Arida S. 2015. Panduan Pengelolaan Desa Wisata Berbasis Potensi Lokal. Bali (ID): Universitas Udayana

Damanik J. 2009. Isu-Isu Krusial dalam Pengelolaan Desa Wisata Dewasa Ini. Jurnal kepariwisataan Indonesia. 5 (3): 127-137

Doembana I, Rahmat A, Farhan M. 2017. Buku Ajar: Manajemen dan Strategi Komunikasi Pemasaran. Yogyakarta (ID): Zahir Publishing

Joshi, Paresh. 2012. "A Stakeholder Networking for Sustainable Rural Tourism Development in Konkan Region of Maharashtra State (India)" Reseach Paper. Narayangaon: Vol.1, Issue. IX. College of Economics and Agricultural Marketing. 
Kotler, P. 2004. "Lateral Marketing: Berbagai Teknik Baru untuk Mendapatkan Ide-Ide Terobosan”. Terj. Oleh Emil Salim dari buku Lateral Marketing New Techniques for Finding Breakthrough Ideas. Surabaya: Erlangga.

Kotler, P. Armstrong G. 2009. Prinsip-Prinsip Pemasaran, Jilid I. Jakarta: Erlangga.

Riduwan. 2008. Metode \& Teknik Menyusun Tesis. Bandung (ID): Alfabeta

Wall M, Wall G. 1982. Tourism Economy Physical and Social Impact. New York (US): Longman Group

Widyastuti S. 2017. Manajemen Komunikasi Pemasaran Terpadu. Jakarta (ID): Universitas Pancasila

Wulan T, Khadiyanto P. 2013. Identifikasi potensi dan masalah Desa Wonosoco dalam upaya pengembangan sebagai desa wisata di Kabupaten Kudus. Jurnal Ruang. 1(1): 81-90. [Internet]. (diakses pada 4 Juli 2020). Dapat diunduh pada: https://ejournal3.undip.ac.id/index.php/ruang/article/view/2877 